\title{
COST ANALYSIS OF REPLACEMENT AND BEARING TRAILER MAINTENANCE IN SUGAR GROUP COMPANIES
}

\author{
Analisis Biaya Penggantian dan Pemeliharaan Bearing Trailer \\ di Sugar Group Companies
}

\author{
Mastur $^{1}$, Masyhuri ${ }^{2}$, Lestari Rahayu Waluyati ${ }^{2}$ \\ ${ }^{1}$ Staff at PT. Indolampung Perkasa, Sugar Group Company, Km. 108 Astra Ksetra, \\ Menggala, Tulang Bawang, Lampung, Indonesia \\ ${ }^{2}$ Faculty of Agriculture, Universitas Gadjah Mada \\ St. Flora, Bulaksumur, Caturtunggal, Depok District, Sleman Regency, Daerah Istimewa \\ Yogyakarta, Indonesia \\ masturilp1@yahoo.com,workshop.ilp@gmail.com
}

Diterima tanggal : 28 Agustus 2017 ; Disetujui tanggal : 6 November 2017

\begin{abstract}
The purpose of this study are to understand (i) the costs and periods optimal of grease used for the replacement and maintenance bearing trailer in Sugar Group Companies (SGC), and (ii) the effect of a period and frequency of grease, lifetime bearing, frequency of replacement bearing in a year, unit trailer, brand bearing, and location of plant. The basic method used is descriptive and analytical. The location determined were in Workshop Division PT. ILP, PT. SIL, and PT. GPM. The analytical method used analytical tables, charts, and multiple regression analysis. The optimal period of grease based on bearing replacement and maintenance costs: (i) PT. ILP both brand A and B: Fertilizer Trailers (FT), Water Tank (WT), Side Tipping Trailer (STT), and Tank Moving (TS) is on 5 days, while Patria (PTR) and Disc Harrow (DH) on 3 days; (ii) PT. SIL both brand A and B unit trailer: FT, WT, PTR, STT, and TS on 5 days unless DH on 3 days; and (iii) PT. GPM for brands B for all unit (FT, WT, PTR, STT, TS, and DH) on 5 days, nor brand A except DH on 3 days. The factors that effect is a period of grease, bearing replacement and frequency of grease in one year. Cost of replacement and maintenance brand A $<$ B. PT. ILP has the lowest costs than PT. SIL and PT. GPM.
\end{abstract}

Keywords : bearing, grease, maintenance, replacement

\section{INTISARI}

Tujuan penelitian mengetahui: (i) biaya dan periode grease optimal untuk penggantian dan pemeliharaan bearing unit trailer di Sugar Group Companies (SGC), dan (ii) pengaruh periode grease, umur pakai bearing, frekuensi penggantian bearing dan grease dalam setahun, unit trailer, merk bearing, dan lokasi pabrik, terhadap biaya penggantian dan pemeliharaan. Metode penelitian adalah deskriptif analitik. Penentuan lokasi di Divisi Workshop: PT. ILP, PT. SIL, dan PT. GPM. Metode analisis yang digunakan adalah berupa analisis tabel, grafik, dan analisis regresi berganda. Hasil penelitian menunjukkan periode grease optimal berdasar biaya penggantian dan pemeliharaan: (i) PT. ILP merk A maupun merk B: Fertilizer Trailer (FT), Water Tank (WT), Side Tipping Trailer (STT), dan Tangki Moving (TS) adalah 5 hari sedangkan Patria (PTR)dan Disc Harrow (DH) 3 
hari; (ii) PT. SIL baik merk A dan B: FT, WT, PTR, STT, dan TS 5 hari, kecuali bearing unit Disc Harrow pada periode grease 3 hari; dan (iii) PT. GPM merk B semua jenis bearing unit trailer (FT, WT, STT, TS, PTR, dan DH) 5 hari, begitu pula merk A kecuali DH 3 hari. Faktor yang berpengaruh terhadap biaya penggantian dan pemeliharaan adalah periode grease, dan frekuensi penggantian bearing dan grease dalam satu tahun.. Biaya penggantian dan pemeliharaan bearing unit trailer merk $A<B$. PT. ILP memiliki biaya penggantian dan pemeliharaan bearing unit trailer paling rendah dibanding $P T$. SIL dan PT. GPM.

Kata Kunci: bearing, grease, pemeliharaan, penggantian

\section{INTRODUCTION}

Generally a product is produced by humans, nothing is impossible to damage, but lifetime can be extended by making known improvements to maintenance (Corder, 1992). A unit or component will experience a decrease in performance in accordance with lifetime of the unit or component. Therefore, maintenance is required which includes maintenance of the units used in the production process in order for the unit or component to function properly and the life of the equipment in accordance with the manufacturer's recommendation.

Every company makes efforts to increase production. And one of the most important thing is to make efficiency. Companies must know the factors that affect the production order increased production and activity production is run efficiently and profitable (Apriawan et al, 2015). Maintenance activities is one effort to improve the efficiency of the company.

The trailer is a vehicle that must be towed by truck or tractor. In sugar cane plantations, trailers are needed as transport units for sugar cane processing up to sugar cane harvesting. The tractor is a vehicle used to pull the trailer and carry other implement. Some trailer unit components should be maintained to keep the unit in good condition. Components that require regular maintenance are wheel bearings. Maintenance of these components with periodic grease lubricant. Maintenance with this lubricant will affect the life of the component. Therefore, it will be further investigated about the optimal bearing replacement and lubrication periods based on the lowest cost of the process.

Sugar group Companies is a company engaged in the field of sugarcane plantations and sugar factories, so that in the process of maintenance of sugar cane in the garden until the harvesting required units of vehicles for transportation of fertilizers, water, diesel, and sugar cane. In the process of transporting fertilizer, water, diesel and sugarcane using a trailer drawn with a tractor. In order for these tractor and trailer units to function properly, routine maintenance is required. 
Constraints arise if routine maintenance is not carried out on the unit, which results in frequent damage to the components of the unit, especially in bearings. With the occurrence of a lot of damage, then the cost incurred for improvement will be great, because the need for replacement bearing components. The objectives of this study were to determine: (i) optimal grease cost and periods used for the replacement and maintenance process of trailer bearing units in SGC, and (ii) grease period effect, bearing trailer life, frequency of bearing replacement in a year, Grease frequency in one year, bearing trailer units, bearing trailer brands, and factory locations affect the cost of replacement and maintenance of bearing trailer units in SGC.

\section{METHODS}

\section{Theoretical Framework}

Less attention to maintenance, among others, caused by the amount of funds needed. However, for the operations of the company, maintenance has become a dual function, namely the implementation and awareness to do maintenance on production facilities. If this maintenance was ignored, it will cause the units decrease in performance, and great maintenance is required because the unit is often damaged.

\section{Maintenance}

Many people assume "Maintenance" is a treatment because most people assume maintenance and treatment have the same meaning, but in reality is different. Maintenance is the action taken on a device or product so that the power product does not suffer damage, the actions taken include the adjustment, lubrication, lubrication checks and replacement of parts that are not feasible anymore. While the treatment is a corrective action taken on a tool that has been damaged for the device to be reused.

\section{Bearing}

In the science of bearing mechanics is an engine element that serves to limit the relative motion between two or more components of the machine to move in the desired direction. Bearing is keeping the shaft to rotate against the axis, or component that moves linearly on track. It must be sturdy enough to withstand the load from the shaft that is connected with other engine components so that it can rotate, work in accordance with its function. If the pads do not work properly, the performance of the entire system will decrease even can be stopped.

Bearing play a pivotal role in rotating machinery. Failure analysis of the bearing is mostly studied by creation of artificial defect on various elements of the bearing and analysis is made with vibration signature tool for monitoring its condition (Kulkarnia and S.B.Wadkarb, 2016). Bearing can be classified based on 
the motion permitted by the bearing design itself, based on the principle of action, and also based on the style or type of load can be resist.

Rolling bearings are essential parts of most rotating machineries, widely used in the industry. They are important supporting components for transmitting motion and bearing loads (Yu et al, 2016). In present study cylindrical roller bearing has been tested in order to investigate its tribological properties. From this experimental study following conclusions have been made (Aditya et al, 2014):

- Initially, wear rates are very small and constant over a period of time. Wear rate accelerates when direct metal to metal contact takes place due to some misalignments during fourth test run.

- Wear particles removed from the inner race are entered in between operating surfaces and results in deterioration of contact surfaces. This wear is further responsible for fatigue failure of the bearing. Due to increase in wear, lubricant film is not capable to form a hydrodynamic film between roller and inner race, and wear particles propagate the wear process.

- Detailed microscopic examination through scanning electron microscope of the inner race and rollers have revealed the presence of pits, cracks at the contact surface and wear debris due to surface contact fatigue.
- Atmospheric conditions influence the wear process a lot. An increase in bearing temperature reduces the lubricant film thickness. The lubricant film between the roller and inner race could not be effectively formed due to increase in bearing temperature, which results in direct contact between two metal surfaces and thus wear takes place.

Bearings with ball type have the ability to spin high rotation and low friction. Bearing can be easily obtained and easy to install. A bearing have a certain shape and size in accordance with the code and has a precision size. Especially for the type of ball bearing with a very small ring, wide per unit area becomes very important. Thus, the material used must also have high resilience and hardness. The material commonly used in the manufacture of bearings is high carbon chromium steel.

The increase of the interference, the balls of the axial and radial displacement of the rings of the ball bearing decreases almost linearly. For small radial loads, the axial displacement slightly differ from each other in magnitude and the radial change equally on all the range of interference on the balls with variation of radial load. Due to the fact that axial displacement practically does not change when the same interference over a range of radial loads, the bearing will have the permanent 
characteristics of the axial stiffness.

This can be very useful in some units of machines and mechanisms, for example in precision machine tools, instrumentation, etc (Barmanov and Ortikov, 2017).

\section{Grease Lubricant}

Grease lubrication is a complex mixture of science and engineering, requiring an interdisciplinary approach, and is applied to the majority of bearings worldwide. Grease can be more than a lubricant (El-Adly and Gamal, 2017). Grease is the oldest type of lubricant. Grease from animal fatty materials has been used from the ancient Egyptian era to lubricate the bearing the shaft of their war machines. While the first grease is made from animal fat, it can be used for lubrication with medium speed and load, while for current technology can not be applied again. High loads, high speed and high temperatures, and some other special requirements must be met by modern grease. Grease generally consists of a solid or semi-fluid two-phase system that is widely used in various application areas as alubricant or sealant (Younes et al, 2016). Modern grease consists of thickener or matrix and base oil (mineral or synthetic oil). Thickener or matrix is usually "metallic soap" (such as sodium, calcium or lithium), clay (bentonite), or synthetic material, the treatment of grease (service) depends on the type of thickener used. In the application, grease can be illustrated like a foam / sponge.

The foam / sponge material can absorb a substantial amount of liquid (in this case oil) which will released out when the foam gets pressure and will be reabsorbed when the pressure on the sponge does not exist anymore. In the case of grease, the thickener or the matrix in grease will absorb the oil And releases it to create lubrication power when the grease is subjected to a large load such as the occurrence of a bearing. When the load is reduced, for example the bearing rotates (and before the next bearing part is exposed), the oil will be reabsorbed into the thickener grease, ready for further lubrication.

Grease is the most widely used lubricant in rolling element bearing applications. Given that early bearing failures are commonly caused by inadequate lubrication, understanding of grease performance in rolling/sliding contacts is vital in terms of improving both bearing life and efficiency. Lubricating greases possess a two phases structure consisting of a thickener in base oil. Lubricant additives are usually added to improve specific aspects of grease performance (Kanazawa et al, 2017).

To increase load-carrying capacity, solid additives such as PTFE (Polytetrafluoroethylene), molybdenum disulfide or graphite (in recent times) are also frequently used. Some other additives may also be used, depending on the needs 
required for some variations of grease. Aditif "Tackiness" is used in the grease to expand grease applications, especially for parts where there is a considerable centrifugal force. Additive anti oxidant is used in grease for industrial applications where service period is more elastic. Rust and corrosion protection is indispensable as an additional protection system.

\section{Basic Method of Research}

The basic method of research used in this research is analytical descriptive method.

The analytic descriptive method has the character of focusing on solving presentday problems, on actual issues. The data collected is initially compiled, explained and then analyzed. The implementation technique in this research is case study, that is focusing attention on a case intensively and detail. The subjects under investigation consisted of one unit (or unit of unit) that was viewed as a case (Surakhmad, 1994).

\section{Research Sites}

The method of determining the location of this research is purposive, that is the object chosen for reasons of knowing the properties of the object based on certain considerations according to the purpose of the research (Surakhmad, 1994). The specified location is the SGC Workshop Division because there has never been any research on replacement and maintenance of tractor bearings and trailers. This division serves as the operational service of units both for maintenance and maintenance unit. This division ensures the readiness of units to be optimal in operation so that the production process runs smoothly.

\section{Data analysis method}

The method of analysis used in this research is the analysis of tables, graphs, and multiple regression.

Hypothesis Testing First

The first hypothesis was tested using a table analysis that looked for the lowest replacement cost and bearing maintenance of the trailer unit for the grease period. Determine the cost of replacement and maintenance of bearings based on bearing replacement frequency and grease bearing period with the following formula:

$i=(f \times g)+h$

where:

$\mathrm{i}=$ replacement cost

$\mathrm{f} \quad=$ frequency of bearing replacement within a year

To determine the value of the replacement frequency in a year (f) is calculated using the following formula:

$$
\begin{aligned}
& \mathrm{f}=\frac{360 \text { (days) }}{\text { Average bearing lifespan (days) }} \\
& \mathrm{g} \quad=\text { replacement cost of bearings } \\
& \mathrm{h} \quad=\text { replacement power costs }
\end{aligned}
$$


Bearing maintenance cost using the following formula:

$$
\mathrm{m}=(\mathrm{j} \times \mathrm{k})+\mathrm{l}
$$

where:

$$
\begin{array}{ll}
\mathrm{m} & =\text { replacement cost } \\
\mathrm{j} & =\text { frequency of grease in a year }
\end{array}
$$

To determine the value of the frequency of grease in a year (j) is calculated using the following formula:

$$
\begin{aligned}
& \mathrm{j}=\frac{360 \text { (days) }}{\text { period of grease (days) }} \\
& \mathrm{k} \quad=\text { cost of replacing grease } \\
& \mathrm{l}=\text { maintenance costs }
\end{aligned}
$$

Second Hypothesis Testing

The second hypothesis was tested using multiple regression analysis. Regression model for cost of replacement and maintenance of bearing unit trailer at SGC on grease period, bearing life, frequency of bearing replacement in a year econometrics can be compiled as follows:

$$
\begin{aligned}
\mathrm{Y}= & \beta_{0}+\beta_{1} \mathrm{X}_{1}+\beta_{2} \mathrm{X}_{2}+\beta_{3} \mathrm{X}_{3}+\beta_{4} \mathrm{X}_{4}+\delta_{1} \mathrm{D}_{1}+ \\
& \delta_{2} \mathrm{D}_{2}+\delta_{3} \mathrm{D}_{3}+\delta_{4} \mathrm{D}_{4}+\delta_{5} \mathrm{D}_{5}+\delta_{6} \mathrm{D}_{6}+ \\
& \delta_{7} \mathrm{D}_{7}+\delta_{8} \mathrm{D}_{8}+\epsilon
\end{aligned}
$$

where :

$$
\begin{aligned}
\mathrm{Y}= & \text { cost of replacement and maintenance } \\
& \text { of trailer bearing units (IDR) } \\
\mathrm{X}_{1}= & \text { period grease (days) } \\
\mathrm{X}_{2}= & \text { The life of the trailer bearing unit } \\
& \text { (days) }
\end{aligned}
$$

$\mathrm{X} 3$ = frequency of bearing replacement in one year (time)

$\mathrm{X} 4$ = frequency of grease in one year (time)

D1 = Dummy bearing trailer unit $(\mathrm{D} 1=1$ if the Fertilizer Trailer unit and D1 $=0$ if other units)

D2 = Dummy bearing trailer unit $(\mathrm{D} 2=$ 1 if the Water Tank unit and D2 = 0 if other units)

D3 = Dummy bearing trailer unit(D3 = 1 if the Patria unit and D3 $=0$ if other units)

D4 = Dummy bearing trailer unit(D4 = 1 if the Side Tipping Trailer unit and D4 = 0 if other units)

D6 = Dummy bearing brand $($ D6 $=1$ if the $\mathrm{A}$ unit and $\mathrm{D} 6=0$ if the $\mathrm{B}$ )

D7 = Dummy factory (D7 $=1$ if the PT. ILP and D7 $=0$ if other factory D8 = Dummy factory (D8 $=1$ if the PT. SIL and D8 $=0$ if other factory)

$\beta 0=$ intercept

$\beta 1, \ldots, 4=$ regression coefficients $\mathrm{X} 1, \mathrm{X} 2$, $\mathrm{X} 3$, and $\mathrm{X} 4$ are estimated $\delta 1, \ldots, 8=$ regression coefficients $\mathrm{D} 1, \ldots$, D8 are estimated

$\varepsilon \quad=$ error term

\section{RESULTS AND DISCUSSION}

\section{Life-wear Bearing Based on Lubrication} Period

Grease is the oldest lubricant type used to be used for lubrication with high speed and load, high speed and high 
temperature. In Table 1 below shows that the life of bearing trailer for PT. ILP based on the grease period on the 6 (six) bearing units studied: Fertilizer Trailer (FT), Water Tank (WT), Patria (PTR), Side Tipping Trailer (STT), Tank Moving (TS), and Disc Harrow (DH) both A and B brands very widely.

Lifetime bearing trailer PT. SIL based on the grease period as in Table 2. In Table 2 below shows that the life of bearing trailer for PT. SIL based on the grease period on the 6 (six) bearing units studied: Fertilizer Trailer (FT), Water Tank (WT), Patria (PTR), Side Tipping Trailer (STT), Tank Moving (TS), and Disc Harrow DH) both $\mathrm{A}$ and $\mathrm{B}$ brands vary widely. Lifetime bearing trailer PT. GPM based on grease period as in Table 3. In Table 3 shows that the life of bearing trailer for PT. GPM based on the grease period on the 6 (six) bearing units studied: Fertilizer Trailer (FT), Water Tank (WT), Patria (PTR), Side Tipping Trailer (STT), Tank Moving (TS), and Disc Harrow DH) both A and B brands vary widely.

The grease for the bearing trailer is intended for bearing trailer maintenance in order to extend the life of the bearing. Based on the data obtained, in Table 1, Table 2, and Table 3, it can be seen that the shorter the days grease period, the longer lifetime bearing trailer. This applies to both brand bearing brand $\mathrm{A}$ and brand $\mathrm{B}$. Based on the table also shows that the lifetime of bearing brand $\mathrm{A}$ is shorter than the lifetime of bearing brand $\mathrm{B}$.

\section{Replacement and Maintenance Cost}

In this research, there are 6 (six) bearing units examined: Fertilizer Trailer (FT), Water Tank (WT), Patria (PTR), Side Tipping Trailer (STT), Tank Moving (TS), and Disc Harrow (DH). From 6 bearing units there are 2 brands, namely brand A and brand $\mathrm{B}$. The six bearing units will be described as follows.

\section{Unit Fertilizer Trailer (FT)}

Table 4 shows the results of the cost analysis of replacement and maintenance of bearing trailers of Fertilizer Trailer units of brand A and brand B on SGC. From Table 4 to PT. ILP bearing trailer of the Fertilizer Trailer unit of both A and $\mathrm{B}$ brands indicates that the 5-day grease period is the optimal period for the replacement and maintenance of the bearing trailer as the total replacement and maintenance cost is the lowest.

Furthermore, the cost of replacing and maintaining the trailer bearing Fertilizer Trailer unit at PT. Both SIL and brand $\mathrm{B}$ brands obtained that the 5 -day grease period is the optimal period for the replacement and maintenance of bearing trailers because the lowest cost is spent. For PT. GPM replacement cost and maintenance of Fertilizer Trailer bearing trailer both A and B brands found that 5-day 
Table 1. Lifetime Data Wear Bearing Trailer PT. ILP

\begin{tabular}{|c|c|c|c|c|c|c|c|c|c|c|c|c|}
\hline \multirow{3}{*}{$\begin{array}{l}\text { Grease } \\
\text { Period } \\
\text { (days) }\end{array}$} & \multicolumn{12}{|c|}{ Lifetime (days) } \\
\hline & \multicolumn{2}{|c|}{ FT } & \multicolumn{2}{|c|}{ WT } & \multicolumn{2}{|c|}{ PTR } & \multicolumn{2}{|c|}{ STT } & \multicolumn{2}{|c|}{ TS } & \multicolumn{2}{|c|}{ DH } \\
\hline & A & $\mathrm{B}$ & A & $\mathrm{B}$ & A & $\mathrm{B}$ & A & $\mathrm{B}$ & A & $\mathrm{B}$ & A & $\mathrm{B}$ \\
\hline 1 & 120 & 138 & 105 & 133 & 68 & 83 & 95 & 103 & 64 & 82 & 85 & 95 \\
\hline 2 & 98 & 103 & 93 & 105 & 60 & 79 & 88 & 98 & 59 & 75 & 75 & 88 \\
\hline 3 & 88 & 95 & 85 & 103 & 58 & 78 & 85 & 93 & 53 & 69 & 60 & 73 \\
\hline 5 & 61 & 82 & 65 & 88 & 35 & 45 & 68 & 93 & 43 & 60 & 35 & 45 \\
\hline 7 & 40 & 53 & 45 & 65 & 28 & 38 & 50 & 65 & 33 & 49 & 15 & 28 \\
\hline 14 & 28 & 35 & 35 & 48 & 25 & 30 & 38 & 45 & 28 & 43 & 15 & 20 \\
\hline 21 & 23 & 25 & 25 & 33 & 18 & 25 & 35 & 45 & 18 & 33 & 15 & 20 \\
\hline 30 & 14 & 17 & 15 & 23 & 8 & 13 & 13 & 20 & 10 & 26 & 15 & 20 \\
\hline
\end{tabular}

Source: Secondary data, processed 2017

Table 2. Lifetime Data Wear Bearing Trailer PT. SIL

\begin{tabular}{|c|c|c|c|c|c|c|c|c|c|c|c|c|}
\hline \multirow{3}{*}{$\begin{array}{l}\text { Grease } \\
\text { Period } \\
\text { (days) }\end{array}$} & \multicolumn{12}{|c|}{ Lifetime (days) } \\
\hline & \multicolumn{2}{|c|}{ FT } & \multicolumn{2}{|c|}{ WT } & \multicolumn{2}{|c|}{ PTR } & \multicolumn{2}{|c|}{ STT } & \multicolumn{2}{|c|}{ TS } & \multicolumn{2}{|c|}{ DH } \\
\hline & A & B & A & $\mathrm{B}$ & A & $\mathrm{B}$ & A & $\mathrm{B}$ & A & B & A & $\mathrm{B}$ \\
\hline 1 & 118 & 138 & 105 & 128 & 67 & 80 & 95 & 103 & 66 & 83 & 83 & 94 \\
\hline 2 & 95 & 108 & 88 & 105 & 57 & 69 & 87 & 100 & 64 & 74 & 76 & 85 \\
\hline 3 & 83 & 98 & 78 & 98 & 50 & 64 & 83 & 98 & 59 & 69 & 68 & 70 \\
\hline 5 & 60 & 85 & 60 & 85 & 43 & 59 & 65 & 88 & 43 & 60 & 38 & 45 \\
\hline 7 & 38 & 58 & 38 & 65 & 34 & 48 & 50 & 65 & 35 & 48 & 31 & 29 \\
\hline 14 & 28 & 33 & 28 & 50 & 33 & 30 & 35 & 50 & 29 & 40 & 26 & 19 \\
\hline 21 & 20 & 23 & 23 & 33 & 25 & 23 & 33 & 38 & 24 & 34 & 18 & 19 \\
\hline 30 & 13 & 18 & 10 & 20 & 9 & 12 & 12 & 18 & 8 & 25 & 18 & 18 \\
\hline
\end{tabular}

Source: Secondary data, processed 2017

Table 3. Lifetime Data Wear Bearing Trailer PT. GPM

\begin{tabular}{|c|c|c|c|c|c|c|c|c|c|c|c|c|}
\hline \multirow{3}{*}{$\begin{array}{l}\text { Grease } \\
\text { Period } \\
\text { (days) }\end{array}$} & \multicolumn{12}{|c|}{ Lifetime (days) } \\
\hline & \multicolumn{2}{|c|}{ FT } & \multicolumn{2}{|c|}{ WT } & \multicolumn{2}{|c|}{ PTR } & \multicolumn{2}{|c|}{ STT } & \multicolumn{2}{|c|}{ TS } & \multicolumn{2}{|c|}{ DH } \\
\hline & A & B & A & B & A & B & A & B & A & B & A & B \\
\hline 1 & 115 & 135 & 104 & 143 & 67 & 75 & 93 & 100 & 64 & 81 & 84 & 93 \\
\hline 2 & 85 & 101 & 88 & 105 & 57 & 71 & 87 & 96 & 59 & 74 & 81.5 & 85 \\
\hline 3 & 80 & 95 & 74.5 & 100 & 48 & 63 & 84 & 94 & 54 & 69 & 65 & 66 \\
\hline 5 & 58 & 83 & 57 & 80 & 39 & 60 & 64 & 87 & 44 & 59 & 37.5 & 49 \\
\hline 7 & 43 & 53 & 38 & 58 & 32 & 48 & 48 & 65 & 35 & 48 & 30 & 27 \\
\hline 14 & 29 & 33 & 24 & 38 & 23 & 28 & 35 & 40 & 28 & 40 & 22.5 & 21 \\
\hline 21 & 18 & 23 & 17.5 & 30 & 18 & 23 & 33 & 40 & 18 & 34 & 17.5 & 20 \\
\hline 30 & 10 & 18 & 8.5 & 25 & 7 & 13 & 17 & 19 & 9 & 25 & 17.5 & 20 \\
\hline
\end{tabular}

Source: Secondary data, processed 2017 
grease period is the optimal period for replacement and maintenance of bearing trailer because the lowest cost is spent. Thus, the overall cost of replacement and maintenance of Fertilizer Trailer trailer trailer units for PT. ILP, PT. SIL and PT. GPM priode grease optimal is 5 days each.

\section{Unit Water Tank (WT)}

Table 5 shows the results of the cost analysis of replacement and maintenance of trailer bearings of Water Tank units of A brand and B brand in SGC. From Table 5 to PT. ILP bearing trailer of Water Tank units of both A and B brands indicates that the 5-day grease period is the optimal period for replacement and maintenance of the bearing trailer because the total replacement and maintenance cost is the lowest. Similarly, the cost of replacing and maintaining the bearing trailer of Water Tank units at PT. SIL, brand A and brand B brands obtained that the 5-day grease period is the optimal period for the replacement and maintenance of bearing trailers because its spent the lowest cost. PT. GPM the cost of replacement and maintenance of bearing trailer of Water Tank unit both brand A and brand B it is found that 5-day grease period is the optimal period for replacement and maintenance of $\mathrm{A}$ brand trailers because the cost is the lowest. Therefore, overall replacement cost And maintenance of bearing trailer unit of Water Tank for PT. ILP, PT. SIL and PT. GPM period grease optimal is 5 days each.

\section{Unit Patria (PTR)}

Table 6 shows the results of the cost analysis of replacement and maintenance of bearing trailer unit of Patria Unit of brand A and brand B of SGC. From Table 6 to PT. ILP bearing trailer of the Patria unit both brand $\mathrm{A}$ and brand $\mathrm{B}$ indicates that the 3-day grease period is the optimal period for replacement and maintenance of bearing trailers because the total replacement and maintenance cost is the lowest. Furthermore, the cost of replacing and maintaining the bearing trailer of the Patria unit at PT. SIL for both A and $\mathrm{B}$ brands found that the 5-day grease period is the optimal period for replacement and maintenance of bearing trailers because the lowest cost. PT. GPM cost of replacement and maintenance bearing trailer of Patria unit either brand A or brand B found that 5-day grease period is the optimal period for replacement and maintenance of bearing trailer because the lowest cost is issued. Thus, overall cost of replacement and maintenance of bearing trailer Unit of Patria for PT. The optimal periode grease ILP is 3 days while for PT. SIL and PT. GPM optimal grease period against the cost of replacing and maintaining the bearing trailer of the Patria unit.

\section{Unit Side Tipping Trailer (STT)}

Table 7 shows the results of the cost analysis of replacement and maintenance of bearing trailer of Side Tipping Trailer units of brand A and brand B on SGC. From Table 7 to PT ILP, PT SIL and PT 
Table 4. Cost Analysis Results on Replacement and Maintenance Fertilizer Trailer in SGC

\begin{tabular}{ccccccc}
\hline \multirow{2}{*}{$\begin{array}{c}\text { Grease } \\
\text { Period } \\
\text { (days) }\end{array}$} & \multicolumn{2}{c}{ PT. ILP } & \multicolumn{2}{c}{ PT. SIL } & \multicolumn{2}{c}{ PT. GPM } \\
\cline { 2 - 7 } & $\mathrm{A}$ & $\mathrm{B}$ & $\mathrm{A}$ & $\mathrm{B}$ & $\mathrm{A}$ & $\mathrm{B}$ \\
\hline 1 & 9.002 .721 & 9.140 .790 & 9.020 .674 & 9.140 .790 & 9.039 .406 & 9.158 .971 \\
2 & 5.212 .233 & 5.490 .845 & 5.239 .561 & 5.429 .585 & 5.364 .948 & 5.510 .405 \\
3 & 4.002 .514 & 4.266 .424 & 4.072 .644 & 4.229 .987 & 4.110 .996 & 4.266 .424 \\
5 & 3.442 .487 & 3.439 .093 & 3.470 .151 & 3.370 .887 & 3.543 .521 & 3.419 .015 \\
7 & 3.858 .450 & 3.898 .629 & 4.027 .200 & 3.675 .026 & 3.709 .553 & 3.898 .629 \\
14 & 4.439 .704 & 4.615 .029 & 4.439 .704 & 4.848 .795 & 4.249 .265 & 4.911 .732 \\
21 & 5.068 .114 & 5.968 .114 & 5.630 .614 & 6.568 .114 & 6.353 .829 & 6.568 .114 \\
30 & 7.686 .394 & 8.636 .070 & 8.554 .251 & 8.168 .537 & 11.112 .146 & 8.168 .537 \\
\hline
\end{tabular}

Source: Secondary data, processed 2017

Table 5. Cost Analysis Results of Replacement and Maintenance of Water Tank Trailer in SGC

\begin{tabular}{cccrrrr}
\hline $\begin{array}{c}\text { Grease } \\
\text { Period } \\
\text { (days) }\end{array}$ & \multicolumn{2}{c}{ PT. ILP } & \multicolumn{2}{c}{ PT. SIL } & \multicolumn{2}{c}{ PT. GPM } \\
\cline { 2 - 7 } & $\mathrm{A}$ & $\mathrm{B}$ & $\mathrm{A}$ & $\mathrm{B}$ & $\mathrm{A}$ & $\mathrm{B}$ \\
\hline 1 & 9.123 .257 & 9.177 .839 & 9.123 .257 & 9.217 .795 & 9.137 .232 & 9.106 .340 \\
2 & 5.268 .366 & 5.459 .486 & 5.330 .914 & 5.459 .486 & 5.324 .340 & 5.459 .486 \\
3 & 4.036 .548 & 4.162 .445 & 4.151 .823 & 4.229 .987 & 4.204 .432 & 4.195 .371 \\
5 & 3.340 .344 & 3.325 .509 & 3.470 .151 & 3.370 .887 & 3.558 .967 & 3.470 .151 \\
7 & 3.577 .200 & 3.404 .123 & 4.027 .200 & 3.404 .123 & 3.991 .674 & 3.675 .026 \\
14 & 3.650 .743 & 3.599 .991 & 4.439 .704 & 3.457 .886 & 4.976 .636 & 4.357 .886 \\
21 & 4.618 .114 & 4.721 .960 & 5.068 .114 & 4.721 .960 & 6.353 .829 & 5.144 .385 \\
30 & 7.204 .251 & 6.454 .251 & 10.579 .251 & 7.204 .251 & 12.366 .016 & 5.854 .251 \\
\hline
\end{tabular}

Source: Secondary data, processed 2017

Table 6. Cost Analysis Results Replacement and Maintenance of Patria Trailer in SGC

\begin{tabular}{ccccccc}
\hline $\begin{array}{c}\text { Grease } \\
\text { Period } \\
\text { (days) }\end{array}$ & \multicolumn{2}{c}{ PT. ILP } & \multicolumn{2}{c}{ PT. SIL } & \multicolumn{2}{c}{ PT. GPM } \\
\cline { 2 - 7 } & $\mathrm{A}$ & $\mathrm{B}$ & $\mathrm{A}$ & $\mathrm{B}$ & $\mathrm{A}$ & $\mathrm{B}$ \\
\hline 1 & 9.658 .971 & 9.795 .335 & 9.681 .528 & 9.846 .471 & 9.681 .528 & 9.958 .971 \\
2 & 5.861 .271 & 5.882 .632 & 5.965 .807 & 6.144 .574 & 5.965 .807 & 6.075 .180 \\
3 & 4.606 .241 & 4.587 .307 & 4.870 .371 & 4.971 .356 & 4.976 .950 & 5.005 .371 \\
5 & 4.675 .509 & 4.782 .651 & 4.165 .004 & 4.070 .787 & 4.412 .522 & 4.032 .651 \\
7 & 5.009 .018 & 4.927 .200 & 4.305 .141 & 4.169 .305 & 4.541 .486 & 4.169 .305 \\
14 & 4.807 .886 & 5.257 .886 & 4.439 .704 & 5.257 .886 & 5.160 .060 & 5.666 .977 \\
21 & 6.353 .829 & 5.968 .114 & 4.618 .114 & 6.568 .114 & 6.193 .114 & 6.568 .114 \\
30 & 13.954 .251 & 11.254 .251 & 12.366 .016 & 12.193 .382 & 16.031 .175 & 11.254 .251 \\
\hline
\end{tabular}

Source: Secondary data, processed 2017 
Table 7. Cost Analysis Results Replacement and Maintenance of Side Tipping Trailer in SGC

\begin{tabular}{ccccccc}
\hline $\begin{array}{c}\text { Grease } \\
\text { Period } \\
\text { (days) }\end{array}$ & \multicolumn{2}{c}{ PT. ILP } & \multicolumn{2}{c}{ PT. SIL } & \multicolumn{2}{c}{ PT. GPM } \\
\cline { 2 - 7 } & $\mathrm{A}$ & $\mathrm{B}$ & $\mathrm{A}$ & $\mathrm{B}$ & $\mathrm{A}$ & $\mathrm{B}$ \\
\hline 1 & 9.224 .761 & 9.476 .045 & 9.224 .761 & 9.476 .045 & 9.253 .566 & 9.508 .971 \\
2 & 5.330 .914 & 5.558 .387 & 5.337 .565 & 5.523 .771 & 5.337 .565 & 5.587 .384 \\
3 & 4.036 .548 & 4.304 .831 & 4.072 .644 & 4.229 .987 & 4.050 .729 & 4.281 .542 \\
5 & 3.282 .651 & 3.242 .111 & 3.340 .344 & 3.325 .509 & 3.377 .140 & 3.343 .345 \\
7 & 3.352 .200 & 3.404 .123 & 3.352 .200 & 3.404 .123 & 3.458 .779 & 3.404 .123 \\
14 & 3.457 .886 & 3.757 .886 & 3.650 .743 & 3.457 .886 & 3.650 .743 & 4.132 .886 \\
21 & 3.460 .971 & 3.568 .114 & 3.683 .499 & 4.168 .114 & 3.683 .499 & 3.943 .114 \\
30 & 8.554 .251 & 7.204 .251 & 9.258 .599 & 8.168 .537 & 6.410 .134 & 7.751 .549 \\
\hline
\end{tabular}

Source: Secondary data, processed 2017

Table 8. Cost Analysis Results Replacement and Maintenance Tank Moving Trailer in SGC

\begin{tabular}{ccccccc}
\hline $\begin{array}{c}\text { Grease } \\
\text { Period } \\
\text { (days) }\end{array}$ & \multicolumn{2}{c}{ PT. ILP } & \multicolumn{2}{c}{ PT. SIL } & \multicolumn{2}{c}{ PT. GPM } \\
\cline { 2 - 7 } & $\mathrm{A}$ & $\mathrm{B}$ & $\mathrm{A}$ & $\mathrm{B}$ & $\mathrm{A}$ & $\mathrm{B}$ \\
\hline 1 & 9.741 .003 & 9.805 .313 & 9.693 .062 & 9.795 .335 & 9.741 .003 & 9.825 .638 \\
2 & 5.904 .541 & 5.985 .852 & 5.768 .260 & 6.010 .506 & 5.904 .541 & 6.010 .506 \\
3 & 4.773 .943 & 4.816 .174 & 4.561 .473 & 4.816 .174 & 4.737 .895 & 4.816 .174 \\
5 & 4.137 .303 & 4.051 .559 & 4.165 .004 & 4.032 .651 & 4.110 .238 & 4.090 .344 \\
7 & 4.442 .585 & 4.110 .705 & 4.220 .057 & 4.169 .305 & 4.261 .983 & 4.169 .305 \\
14 & 4.439 .704 & 4.132 .886 & 4.249 .265 & 4.132 .886 & 4.373 .957 & 4.132 .886 \\
21 & 6.353 .829 & 4.659 .023 & 4.786 .864 & 4.597 .965 & 6.353 .829 & 4.597 .965 \\
30 & 11.112 .146 & 5.646 .559 & 13.954 .251 & 5.854 .251 & 11.704 .251 & 5.854 .251 \\
\hline
\end{tabular}

Source: Secondary data, processed 2017

GPM bearing trailer of Side Tipping Trailer indicates that the 5-day grease period is the optimal period for replacement and maintenance of bearing trailers because the lowest total replacement and maintenance cost. Between two brand (brand A and brand $\mathrm{B}$ ), brand $\mathrm{B}$ is cheaper than brand $\mathrm{A}$ for replacement and maintenance cost of side tipping trailer in SGC.

\section{Unit Tangki Moving (TS)}

Table 8 shows the results of the cost analysis of replacement and maintenance of trailer bearings of the Tank Moving unit of brand A and brand B of the SGC. From Table 8 below shows the results of the cost analysis of replacement and maintenance of bearing trailer of Tank Moving units of brand A and brand B on SGC. From Table 7 to PT ILP, PT SIL and PT GPM bearing trailer of Tank Moving indicates that the 5-day grease period is the optimal period for replacement and maintenance of bearing trailers because the lowest total replacement and maintenance cost. Between two brand (brand A and brand 
Table 9. Cost Analysis Results of Replacement and Maintenance of Disc Harrow Trailer in SGC

\begin{tabular}{ccccccc}
\hline \multirow{2}{*}{$\begin{array}{c}\text { Grease } \\
\text { Period } \\
\text { (days) }\end{array}$} & \multicolumn{2}{c}{ PT. ILP } & \multicolumn{2}{c}{ PT. SIL } & \multicolumn{2}{c}{ PT. GPM } \\
\cline { 2 - 7 } & & $\mathrm{B}$ & $\mathrm{A}$ & $\mathrm{B}$ & $\mathrm{A}$ & $\mathrm{B}$ \\
\hline 1 & 9.350 .148 & 9.580 .024 & 9.386 .244 & 9.595 .142 & 9.364 .329 & 9.618 .431 \\
2 & 5.523 .771 & 5.716 .629 & 5.506 .008 & 5.762 .007 & 5.416 .103 & 5.762 .007 \\
3 & 4.532 .871 & 4.707 .440 & 4.345 .371 & 4.773 .943 & 4.403 .064 & 4.890 .826 \\
5 & 4.675 .509 & 4.782 .651 & 4.482 .651 & 4.782 .651 & 4.482 .651 & 4.537 .753 \\
7 & 8.077 .200 & 6.236 .291 & 4.646 .872 & 5.982 .372 & 4.702 .200 & 6.327 .200 \\
14 & 7.507 .886 & 7.507 .886 & 4.652 .116 & 7.863 .149 & 5.257 .886 & 7.343 .252 \\
21 & 7.318 .114 & 7.318 .114 & 6.193 .114 & 7.673 .377 & 6.353 .829 & 7.491 .191 \\
30 & 7.204 .251 & 7.204 .251 & 6.079 .251 & 8.168 .537 & 6.239 .966 & 7.377 .328 \\
\hline
\end{tabular}

Source: Secondary data, processed 2017

B), brand B is cheaper than brand A for replacement and maintenance cost of Tank Moving in SGC.

\section{Unit Disc Harrow (DH)}

Table 9 below shows the results of the cost analysis of replacement and maintenance of bearing trailers of Disc Harrow brands A and B brands in SGC. From Table 9 for PT ILP and PT SIL bearing trailer of the Disc Harrow unit show that the 3-day grease period is the optimal period for the replacement and maintenance of the bearing trailer as the total replacement and maintenance cost is the lowest. Brand A is cheaper than brand $\mathrm{B}$ for the replacement and maintenance cost of disc harrow unit in SGC.

\section{Factors Affecting Replacement and Maintenance Costs}

To estimate the function of factors affecting the cost of replacement and maintenance of bearing trailers in SGC done by multiple linear regression analysis with OLS method. Factors suspected to affect the cost of replacement and maintenance of bearing trailers in Sugar Group Companies are: (i) grease period, (ii) bearing trailer life, (iii) frequency of bearing replacement in a year, (iv) grease frequency in one year, (v) bearing trailer unit, (vi) bearing trailer brand, and (vii) factory location. Based on the results of the analysis in Table 10, the econometric model obtained at the replacement cost equation and bearing trailer maintenance in Sugar Group Companies in chapter 3 is as follows:

$$
\begin{aligned}
\mathrm{Y}= & 193.370,70+296,98 \mathrm{X}_{1}-32,14 \mathrm{X}_{2} \\
& +281.197,60 \mathrm{X}_{3}+39.958,67 \mathrm{X}_{4} \\
& -13.069,43 \mathrm{D}_{1}-10.566,80 \mathrm{D}_{2} \\
& +850,29 \mathrm{D}_{3}+915,48 \mathrm{D}_{4}+ \\
& 3.115,27 \mathrm{D}_{5}-6.487,36 \mathrm{D}_{6}- \\
& 11.601,96 \mathrm{D}_{7}-95,23 \mathrm{D}_{8}+\epsilon
\end{aligned}
$$


The overall test of the results of the analysis of factors suspected to affect the cost of replacement and maintenance of bearing trailer in SGC obtained the value of coefficient of determination $\left(\mathrm{R}^{2}\right)$ of 0.9869 . This shows that approximately $98.69 \%$ of the variation in replacement and maintenance costs of bearing trailers in SGC can be explained by: (i) grease period, (ii) bearing trailer life, (iii) frequency of bearing replacement in a year, (iv) the frequency of grease in a year (v) the bearing trailer unit, (vi) bearing trailer brand, and (vii) the factory location while the rest $(2.31 \%)$ is explained by other independent variables outside the analytical model used.

To see the overall effect of the independent variables: (i) the grease period, (ii) the life of the trailer bearing unit, (iii) the frequency of bearing replacement in a year, (iv) the frequency of grease in a year, (v) the bearing trailer unit, (v) the bearing unit of the trailer, (vi) bearing trailer brand, and (vii) factory location for replacement cost and maintenance of bearing trailer in SGC is used overall test (F-test). Based on the results of the analysis in Table 10 is below obtained F-count value of 330,910 and this value is much greater than the $\mathrm{F}$-table value shown in very low probability F-statistic (probability $<1 \%$ ). This indicates that the variables are: (i) the period of grease, (ii) the life of the trailer bearing unit, (iii) the frequency of bearing replacement in a year, (iv) the grease frequency in one year, (v) the bearing trailer unit, (vi) bearing trailers brand, and (vii) factory locations in the model together have a significant effect on the cost of replacement and maintenance of bearing trailers in SGC at a $99 \%$ confidence level.The results of the analysis of factors affecting the cost of replacement and maintenance of bearing trailers in SGC as shown in Table 10 below.

To see the effect of each independent variable, namely: (i) the grease period, (ii) the life of the trailer bearing unit, (iii) the frequency of bearing replacement in a year, (iv) the frequency of grease in a year, (v) the bearing trailer unit, (ii) the frequency of grease replacement in a year, (v) the unit trailer, (vi) the brand bearing trail; and (vii) factory locations for replacement and maintenance cost of bearing trailers in SGC are used individually test (t-test) test. Based on the results of the t-test analysis in table 10 above shows that the grease period, the frequency of bearing replacement in one year, and the grease frequency in one year statistically show significant effect on replacement cost and bearing trailer independent variable age of bearing unit trailer on statistics did not show any real difference (non significant).

In the empirical analysis, good or bad model is not only seen from the value of the coefficient of determination $\left(\mathrm{R}^{2}\right)$ which is obtained but also must see the matching of the sign of regression coefficient with economic theory. The 
Table 10. Factors Affecting Replacement and Maintenance Costs Trailer Bearing of SGC

\begin{tabular}{|c|c|c|c|c|}
\hline No, & Independent Variable & $\begin{array}{l}\text { Regression } \\
\text { coefficient }\end{array}$ & $\mathrm{t}$-count & Prob, \\
\hline 1 , & Grease period & 296.98 & 2.457 & 0.0035 \\
\hline 2 & Age wear bearing unit trailer & -32.14 & -0.765 & 0.4449 \\
\hline 3 , & Frequency of bearing replacement in one year & $281,197.60$ & 720.236 & 0.0000 \\
\hline 4 & Frequency of grease in one year & $39,958.67$ & $1,508.936$ & 0.0000 \\
\hline 5 , & $\begin{array}{l}\text { Dummy bearing trailer unit }\left(D_{1}=1 \text { if the Fertilizer }\right. \\
\text { Trailer unit and } D_{1}=0 \text { if other units) }\end{array}$ & $-13,069,43$ & -1.691 & 0.0919 \\
\hline 6 , & $\begin{array}{l}\text { Dummy bearing trailer unit }\left(\mathrm{D}_{2}=1 \text { if the Water }\right. \\
\left.\text { Tank unit and } \mathrm{D}_{2}=0 \text { if other units }\right)\end{array}$ & $-10,566,80$ & -1.453 & 0.1472 \\
\hline 7 , & $\begin{array}{l}\text { Dummy bearing trailer unit }\left(\mathrm{D}_{3}=1 \text { if the Patria }\right. \\
\text { unit and } \mathrm{D}_{3}=0 \text { if other units) }\end{array}$ & 850.29 & 0.118 & 0.9062 \\
\hline 8 & $\begin{array}{l}\text { Dummy bearing trailer unit }\left(\mathrm{D}_{4}=1 \text { if the Side }\right. \\
\left.\text { Tipping Trailer unit and } \mathrm{D}_{4}=0 \text { if other units }\right)\end{array}$ & 915.48 & 0.126 & 0.8997 \\
\hline 9, & $\begin{array}{l}\text { Dummy bearing trailer unit }\left(D_{5}=1 \text { if the Tangki }\right. \\
\text { Moving unit and } D_{5}=0 \text { if other units) }\end{array}$ & $3,115.27$ & 0.376 & 0.7070 \\
\hline 10, & $\begin{array}{l}\text { Dummy bearing brand }\left(\mathrm{D}_{6}=1 \text { if the } A \text { unit and } \mathrm{D}_{6}\right. \\
=0 \text { if the } \mathrm{B})\end{array}$ & $-6,487.36$ & -3.023 & 0.0071 \\
\hline 11, & $\begin{array}{l}\text { Dummy factory }\left(\mathrm{D}_{7}=1 \text { if the PT, ILP and } \mathrm{D}_{7}=0 \text { if }\right. \\
\text { other factory) }\end{array}$ & $-11,601.96$ & -2.052 & 0.0411 \\
\hline 12 , & $\begin{array}{l}\text { Dummy factory }\left(\mathrm{D}_{8}=1 \text { if the PT, SIL and } \mathrm{D}_{8}=0 \text { if }\right. \\
\text { other factory) }\end{array}$ & -95.23 & -1.870 & 0.0495 \\
\hline 13, & Intercept & $193,370.70$ & 21.318 & 0.0000 \\
\hline & Coefficient of determination $\left(\mathrm{R}^{2}\right)$ & 0.9869 & \multirow{3}{*}{\multicolumn{2}{|c|}{$330,910.00$}} \\
\hline & F- count & & & \\
\hline & Number of samples (n) & 288 & & \\
\hline
\end{tabular}

Source: Secondary data, processed 2017

where: $* * *)$ significant on $\alpha=1 \%$;

*) significant on $\alpha=10 \%$;

description of the factors that affect the cost of replacement and maintenance of bearing trailers in SGC contained in the regression model that has been prepared are as follows:

\section{Grease period}

In Table 10 the grease period statistically showed a significant and positive effect on the cost of replacement and maintenance of bearing trailer in SGC at 99\% confidence

$$
\begin{aligned}
& * *) \text { significant on } \alpha=5 \% \text {; } \\
& \mathrm{NS}=\text { non significant }
\end{aligned}
$$

level with regression coefficient value of 296,99999 . The sign of grease period variable coefficient is positive. The sign of the grease period variable coefficient. This means that if the grease period increases by 1 day assuming other.

\section{Frequency of bearing replacement in one year}

The results of the analysis in Table 10 show that the frequency variables of bearing 
replacement in one year statistically show a significant and positive influence on the cost of replacement and maintenance of bearing trailers in SGC at a $99 \%$ confidence level. The regression coefficient value of the frequency variation of bearing replacement in one year is $\mathrm{Rp} 281.197,60$. Positive slopes on variable frequency coefficient of bearing replacement in one year according to economic theory. This means that if the frequency of bearing replacement in one year increases one time with the factors in cateris paribus condition, the cost of replacement and maintenance of bearing trailer in SGC has increased by $\operatorname{Rp} 296,9799$. This means that if the grease period increases then there is a tendency for replacement cost and bearing trailer maintenance in SGC to increase. As the initial hypothesis proposes that the relationship between the grease period and the cost of replacement and maintenance of bearing trailers in SGC is positive. If the grease period increases then the cost of replacement and maintenance of bearing trailers in SGC will be increased as well.

Assumption that other factors are in cateris paribus condition, the cost of replacement and maintenance of bearing trailer in SGC has increased by Rp 281.197,60. This means that if the frequency of bearing replacement in one year increases then there is a tendency for replacement cost and maintenance of bearing trailer in SGC to increase. As the initial hypothesis proposes that the relationship between the frequency of bearing replacement within a year and the cost of replacement and maintenance of bearing trailers in SGC is positive. If the frequency of replacement bearing in one year increases then the cost of replacement and maintenance of bearing trailer in SGC period $t$ will also increase.

\section{Frequency of grease in one year}

Based on the results of the study as shown in Table 10 shows that the grease frequency in one year statistically shows a significant and positive influence on the cost of replacement and maintenance of bearing trailers in SGC at a 99\% confidence level. The value of the regression coefficient of the grease frequency variables in one year

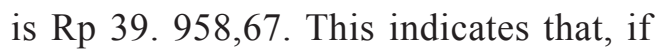
the grease frequency in one year increases one time assuming other factors are fixed, the cost of replacing and maintaining the bearing trailer in SGC will increase by the regression coefficient value of the grease frequency variable in one year $(\mathrm{Rp}$ $39.958,67$ ) or Rp 39.958,67.

\section{Bearing trailer unit}

In this research, there are 6 units of bearing trailer being investigated: Fertilizer Trailer, Water Tank, Patria,Side Tipping Trailer, Moving Tank, and Disc Harrow. To distinguish between 6 units of bearing trailer there is a difference 
of replacement cost and maintenance of bearing trailer in SGC made variable of doll or artificial (dummy variable). Variables $\mathrm{D}_{1}$ through $\mathrm{D}_{5}$ are the dummy variables of the bearing trailer units in SGC. Based on the results of the analysis in Table 10 above shows that only $\mathrm{D}_{1}$ variable is statistically significant affect the cost of replacement and maintenance of bearing trailer in $\mathrm{SGC}$ at $90 \%$ confidence level. The value of regression coefficient of variable $\mathrm{D}_{1}$ is $-13.069,43$. This shows that there is a difference in replacement cost and maintenance of bearing trailer in SGC Fertilizer Trailer bearing units of other trailer bearing units (Water Tank, Patria, Side Tipping Trailer, Moving Tank, and Disc Harrow) where Fertilizer Trailer bearing unit is lower Rp.13.069,43. Whereas between the Water Tank bearing unit, Patria, Side Tipping Trailer, Moving Tank, and Disc Harrow there is no significant difference in the cost of replacement and maintenance.

\section{Bearing brand}

In Table 10 above shows that $\mathrm{D}_{6}$ (brand bearing) is statistically significant and negative to the cost of replacement and maintenance of bearing trailer in SGC at $99 \%$ confidence level. The value of regression coefficient of variable $D_{6}$ is $-6.487,36$. It shows that there are differences in the cost of replacement and maintenance of bearing trailers in SGC on bearing trail brands in which brand $\mathrm{A}$ is lower $(\mathrm{Rp} 6.487,36)$ than brand B.

\section{Factory Location}

Table 10 above shows that $\mathrm{D}_{7}$ and $\mathrm{D}_{8}$ (factory locations) are statistically significant (significant) and negative to the cost of replacement and maintenance of bearing trailers in SGC at a $95 \%$ confidence level. The value of regression coefficient of $D_{7}$ variable is $-11.601,96$ and $D_{8}$ is $-95,23$. This shows that there is a difference in replacement cost and maintenance of bearing trailer between SGC (PT ILP, PT SIL, and PT GPM) where PT. ILP has the cost of replacement and maintenance of the lowest bearing trailer that is $\mathrm{Rp} 11.601,96$ compared to PT. SIL and PT. GPM or in other words PT. GPM has the cost of replacing and maintaining the largest bearing trailer.

\section{Comparison of Research Results}

Bearings used in this study is bearing roller. Based on previous research rolling element bearings or ball/roller bearings are most common machine component of any rotating machinery used in industry. Rolling element bearings endure heavy loads under industrial operating conditions and structural faults, such as wear, pitting, or spall may occur after a long period of running. A defect in bearing if remain undetected would cause its break down and 
may ultimately cause catastrophic failure of the machinery. Therefore, early detection of bearing defects is the most important for effective condition monitoring of industrial plant (Tyagi and Panigrahi, 2017).

\section{CONCLUSION AND SUGGESTION}

\section{Conclusion}

Based on the results of research on cost analysis of replacement and maintenance of bearing trailer in SGC, it can be concluded as follows:

1. Period of grease cost of replacement and maintenance of trailer bearing unit in SGC optimal, that is:

a. PT. ILP both brand A and brand B for bearing trailer units: Fertilizer Trailer, Water Tank, Side Tipping Trailer and Moving Tank are 5 days grease period while bearing Patria and Disc Harrow trailer units in 3-day grease period.

b. PT. SIL both A and B brands of all types of trailer bearing units: Fertilizer Trailer, Water Tank, Patria, Side Tipping Trailer and Moving Tank in 5-day grease period except Disc Trailer bearing unit of Disc Harrow in 3-day grease period.

c. PT. GPM for B brands of all types of trailer bearing units (Fertilizer Trailer, Water Tank, Patria, Side Tipping Trailer, Moving Tank and Disc Harrow) in 5-day grease period, as well as A brand except the Disc Harrow trailer trailer in 3-day grease period.

2. Factors affecting the cost of replacement and maintenance of bearing trailers in SGC are the period of grease, the frequency of bearing replacement in one year, and the frequency of grease in one year.

3. Fertilizer Trailer bearing units have the lowest replacement cost and bearing trailer maintenance in SGC compared to other bearing trailer units (Water Tank, Patria, Side Tipping Trailer, Tank Moving and Disc Harrow).

4. Bearing replacement frequency in one year have positive effect on replacement cost and maintenance of bearing trailer, if the bearing replacement frequency in one year increase one time then replacement cost and maintenance of bearing trailer in SGC increased by $\mathrm{Rp}$ 281.197,60.

5. The frequency of grease in one year has a positive effect on replacement cost and maintenance of bearing trailer, if the frequency of grease in one year increase one time, the cost of replacement and maintenance of bearingtrailer in SGC increased by $\mathrm{Rp}$ 39,958.67.

6. Brand A has the cost of replacement and maintenance of bearing trailer in SGC lower Rp.6.487,36 compared to $\mathrm{B}$. 
7. PT. ILP has the lowest replacement cost and bearing trailer maintenance compared to PT. SIL and PT. GPM (PT GPM has the largest replacement cost and bearing trailer maintenance).

\section{Suggestion}

Based on the conclusion of the research result about the cost analysis of replacement and maintenance of trailer bearing unit in Sugar Group Companies, can be submitted suggestions as follows:

1. Replacement and maintenance of bearing trailer units in Sugar Group Companies to optimally need to pay attention to the period of grease which has the lowest cost or the smallest, in the grease period of 3 days up to 5 days.

2. To optimize replacement cost and maintenance of trailer bearing unit in Sugar Group Companies needs to pay attention to variable of grease period, bearing replacement frequency in one year, and frequency of grease in one year because the variable is statistically significant to cost of replacement and maintenance of bearing unit trailer.

3. To reduce the cost of replacement and maintenance of bearing trailer units in Sugar Group Companies, preferably PT. ILP, PT. SIL, and PT. GPM uses A brand bearings.

\section{REFERENCES}

Aditya, M. Amarnath, and P.K. Kankar. 2014. Failure analysis of a greaselubricated cylindrical roller bearing. Procedia Technology 14 : 59-66.

Apriawan, Derry Candia., Irham, and Jangkung Handoyo Mulyo. 2015. Analysis of sugarcane and sugar production in PT. Perkebunan Nusantara VII (PERSERO). Agro Ekonomi Vol. 26 (2) : 159-167.

Barmanov I.S., and Ortikov M.N. 2017. Ball bearing dynamics at the interference fit on balls. Procedia Engineering $176: 19-26$.

Corder, AS. 1992. Teknik Manajemen Pemeliharaan. Jakarta : Erlangga.

El-Adly, Refaat A., and Gamal M. Turky. 2017. Comparative study between prepared electrical grease and the imported one. Egyptian Journal of Petroleum.

Kanazawa, Yuta., Richard S. Sayles, and Amir Kadiric. 2017. Film formation and friction in grease lubricated rolling-sliding non-conformal contacts. Tribology International 109 : 505-518.

Kulkarnia, Sham., and S.B.Wadkarb. 2016. Experimental investigation 
for distributed defects in ball bearing using vibration signature analysis. Procedia Engineering 144 : 781-789.

Surakhmad, W. 1994. Penelitian Ilmiah, Dasar, Metode, dan Teknik. Bandung : Tarsito.

Tyagi, Sunil., and SK Panigrahi. 2017. An improved envelope detection method using particle swarm optimisation for rolling element bearing fault diagnosis. Journal of Computational Design and Engineering.
Younes, Hammad., Greg Christensena, Lori Grovenb, Haiping Honga, and Pauline Smithca. 2016. Three dimensional (3D) percolation network structure: key to form stablecarbon nano grease. Journal of Applied Research and Technology 14 : 375-382.

Yu, Guangwei, Meng Su, Wei Xia, Rui Wu, and Qing Wang. 2017. Vibration characteristics of deep groove ball bearing based on 4-DOF mathematical model. Procedia Engineering 174 : 808-814 